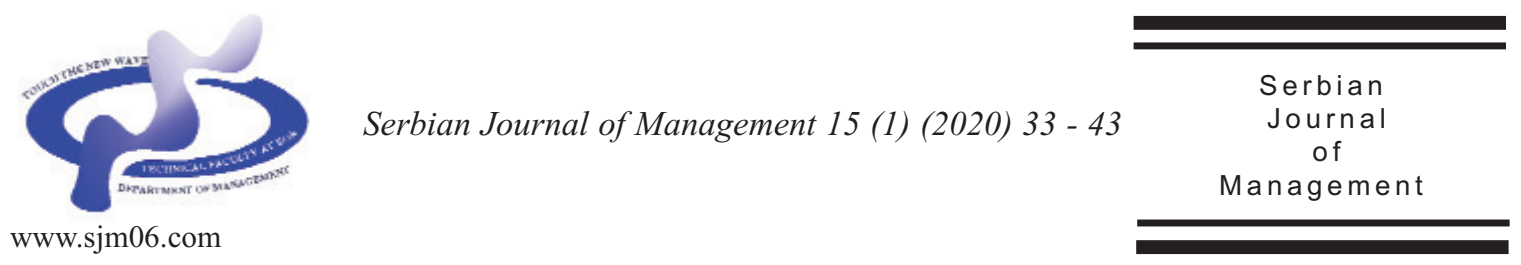

\title{
THE ECONOMIC FEASIBILITY OF CRANE CABINS WITH REAL-TIME COMPUTER-AIDED VISUAL GUIDANCE SYSTEM
}

\author{
Nikola Dondura, Vesna Spasojević Brkića* ${ }^{*}$, Aleksandar Brkićb and Martina Perišića

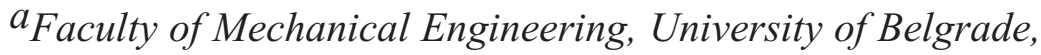 \\ Kraljice Marije 16, Belgrade, Serbia

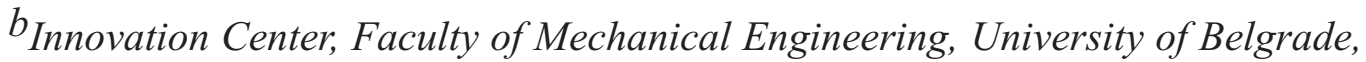 \\ Kraljice Marije 16, Serbia
}

(Received 18 November 2019; accepted 18 December 2019)

\begin{abstract}
Cranes' operations are extremely risky and hazardous tasks, as demonstrated in various surveys in the field of incidents' causes and effects. The most frequent cause of unsafe crane operation task execution is human error. Accordingly, innovation which enables cranes' safe operations, prevents "blind lifts" and helps crane operator to avoid potential error is urgent. Project SPRINCE has proposed computer-aided Visual Guidance System as a real time solution aimed to prevent crane accidents, caused by obstructed view. This paper analyses the economic feasibility of Visual Guidance System application in various scenarios in aim to connect human, technology and organization issues through cost-benefit framework. There are two proposed investment scenarios analysed: A) Producing and selling of crane cabins with real-time computer-aided Visual Guidance System and B) Usage (purchase) of crane cabins with real-time computer-aided Visual Guidance System. The economic appraisal has proved that the total economic benefit in both scenarios in the complete utilization period is several times higher than the buying price, while the internal rate of return is few times higher than the aggregate rate of interest paid. Also, the amount of time which takes to recover the cost of an investment is less than four years. Moreover, both scenarios belong to the category of innovation projects with very low risk.
\end{abstract}

Keywords: crane cabins, visual guidance system, economic appraisal, safety

*Corresponding author: vspasojevic@mas.bg.ac.rs

DOI: $10.5937 /$ sjm 15-24058 


\section{INTRODUCTION}

Cranes represent the most dangerous of all equipment that is used at industrial and construction sites (Neitzel et al., 2001; Beavers et al., 2006; Poh et al., 2018). In the intermodal transport and chemical process, danger of crane-related accidents can have serious consequences such as explosions, fires, the spread of toxic substances with domino effects (Fabiano \& Curro, 2012; Milazzo et al., 2016). The main cause of crane-related accidents is human error (Spasojević-Brkić et al., 2015.; Milazzo et al, 2016). Considering power and size of available cranes, possibility of life losing accidents and material damage is huge. Workers can be injured, or machines and devices can be upset by a mishandled, tripped or dropped load (Spasojević-Brkić et al., 2015a). Not only those who are directly involved, but also the pedestrians are in the risk of being killed or injured (Shin, 2015). The material cost of cranes accidents is very high (Chu \& Thi, 2018). The increase of technical quality of cranes leaded to reduced crane accidents caused by 'jib instability', 'hoisting equipment instability', and 'crane instability'. In spite of that, human error still represents the unsolved problem which still leads to serious accidents (Uth \& Weiste, 2004; Fang et al., 2018). Hence, special attention should be given to the craneoperator's workplace, with the aim to come closer to Industry 4.0 concept, make it "smarter" and help operator to avoid accidents and prevent losses of life, material damage, occupational injuries, illnesses, and other undesired events.

Previous research have reflected the need that cranes designers have to take more care and pay more attention to design future cranes in manner that they fulfil requests for safer operation, better maintenance and solved human factors issues (Marhavilas et al., 2011; Pinto et al., 2011; Skogdalen \& Vinnem, 2011; EU OSH Strategy, 20142020).

Current accident theories indicate that it is possible to reduce human errors through innovations that will help operator not to make mistake instead of focusing on correction of operator's behavior. For that reason, the crane navigation system represents very challenging and significant phenomenon that has a huge potential to improve safety. Number of typical crane controls to be manipulated is low and mostly related to quick and accurate spread with or without load and it gives a false feeling of simplicity to crane operator. In reality, operators need to have a great sense of cranes dynamics that includes stopping the moving mass before it achieves "stabbing in the blind" scenario. That is the situation where operators need help. Also, in recent years, it is proposed that exploiting the potential of "smart" technologies has potential to improve the industrial and occupational safety (Ansaldi et al., 2018).

Those facts indicate that there is a real need for the innovation that contains smart crane navigation system - visual guidance system (VGS). VGS represents solution that is challenging, important and has a great perspective to increase safety. The proposed VGS stereoscopically screens the work space on site and gives to operator both data and alert in aim to easily prevent collision, as described in detail in Ancione et al. (2017). It is real-time system which uses a colour webcameras with purpose to get the relative coordinates of hook, cabin and obstractions, calculates distance between them and creates visual and audio signals to guide operator to take corrective actions when needed 
(Ancione et al., 2017). Using of VGS enables operators' to execute their jobs in safer, more comfortable and much less stressful manner.

\section{POSSIBLE SCENARIOS}

Investors usually have a fairly large number of dispositional alternatives (Puška et al., 2018). So, the economic feasibility of VGS installed will be examined in the following two scenarios:

A) Production and sale of crane cabin with VGS and

B) Usage (purchase) of crane cabin with VGS.

Economic and financial feasibility in the scenario A assumes defining the standard parameters of the appraisal from cabin producer and overall economy view (Dondur, 2002). The scenario B aims at assessment of feasibility of investing into innovative crane cabins usage. Comparison of initial investment costs and discounted additional effects/savings in the crane exploitation over its lifecycle is done through analyses of net economic benefits, identification and quantification of relevant costs and effects (Rosenfeld \& Shapira, 1998; Neitzel et al., 2001; Dondur, 2002; Beavers et al., 2006; Vianello et al., 2019).

\subsection{Scenario A}

The investment in construction works amounts 800.000 EUR while investment in mechanical equipment amounts 480.150 EUR, which amounts in total 1.280.150 EUR. Crane cabin production costs are as given in Table 1.Total material and parts cost 6.470 EUR. If there is a labor force of 20 employees and production volume of 200
Table 1. Crane cabin production costs

\begin{tabular}{ll}
\hline Crane cabin production costs & EUR \\
\hline Air conditioning device & 1.445 \\
Steel & 600 \\
Glass & 575 \\
Painting material & 150 \\
Electrical/Control equipment & 2.600 \\
VGS & 1.100 \\
\hline
\end{tabular}

cabins per year, cost of labor per cabin amounts 750 EUR. Maintenance costs are calculated as percent of total value of investment, while amortization is calculated by proportions method in the exploitation period (20 years). In the planned exploitation period equipment is fully depreciated, while production site has value of 160.000 EUR. The planned maximum production capacity of 200 cabins would be reached in the third year.

In the first two years of exploitation, the capacity would be used with $75 \%$ and $83 \%$ of the maximum capacity. The stock of ready-made cabins is planned on a monthly basis (17 at full capacity). The receivables, as part of the working capital, are planned on a monthly basis. The projected selling price is the main price on the international market for similar products and amounts to 10.000 euros per sold cabin. The average annual sales revenue at constant prices is 1.833 .333 euros. Table 3 provides an overview of the aggregate values of the basic positions of the projected profit and loss. Aggregate income statement items are given in Table 2.

Table 2. Aggregate income statement

\begin{tabular}{ll}
\hline $\begin{array}{l}\text { Aggregate income statement } \\
\text { items }\end{array}$ & EUR \\
\hline Total income & 36.063 .333 \\
Total expenditures & 31.076 .998 \\
Profit before tax & 4.986 .335 \\
Net profit & 4.487 .701 \\
\hline
\end{tabular}


The average annual net profit of the factory is 224.385 euros. Project profitability indicators are given in Table 3.

The net present value of this project amounts 1.312.721 euros and it is evident that it much higher than the initial project costs in several ways. The discounted net flow at a rate of return in alternative investment of $10 \%$ amounts to 13.127.210 euros, which is more than the initial investment costs.

By reducing the discount rate, the net present value increases dramatically. The net present value can be calculated at a lower discount rate, taking into account the relevant interest rate on the domestic financial market. With a discount rate which amounts 5\%, net present value is twice higher than the initial investment. Following the criteria for assessing the justification of this project is acceptable. There is an internal rate of return which amounts $24.4 \%$ and it is several times higher value than the relevant interest rate (capital price), according to Curry \& Weiss (2000). The project for the construction of a factory for the production of cabins with previously defined technology and the volume of production is economically justified by this criterion. The time horizon for the investment return amounts 4.1 years. Return of investment period is common and expected period for similar projects in metalworking industry. Sensitivity analysis through the determination of switching critical values identifies project sizes (components) that need to be addressed. Sensitive project components are usually defined as those sizes whose small changes contribute to a significant shift in the results of the analysis model. However, the

\section{Table 3. Project profitability indicators}

\begin{tabular}{lll}
\hline Profitability indicators & Value & Unit \\
\hline Net present value & 1.312 .721 & EUR \\
$\begin{array}{l}\text { Internal rate of return } \\
\begin{array}{l}\text { Investment return period } \\
\text { (undiscounted) }\end{array}\end{array}$ & $4,1,43 \%$ & $\%$ \\
\hline
\end{tabular}

certainty associated with these sizes may be smaller or larger. Not all sensitive variables are simultaneously variable with great uncertainty. For a component of a project to assess risk, in addition to being sensitive, it must also be highly uncertain. The volume of initial investment is a sensitive component of the project in that relatively small changes in the value of those assets significantly shift the net present value or the internal rate of return, but since the investment funds are already provided and the project plan defines their volume, it does not make much sense to calculate the probability that these funds are, to that extent, realized. The value of these funds may possibly be affected by the time at which the investment began, and therefore it is more reasonable to account for the probability of delay in the beginning of the project. Theoretically, of course, every variable is a random variable, and it makes sense for each variable to account for the probability of an event. Project analysis is about practical models and the tendency to shorten the risk analysis procedure as much as possible while preserving the elementary computational consistency. The sensitivity and uncertainty of a project component are two basic characteristics to characterize that component as a critical component of a project and to measure event certainty for that component, that is, to calculate the probability of an event. Therefore, in order to move on to project risk assessment, it is necessary to define the critical components of the project. Each critical component of a project must be computed with an event probability, as these probabilities also determine the probability of the output of the project analysis model. Sensitivity analysis gives results as shown in Table 4.

Sensitivity analysis arrives to conclusion that this is a project with acceptable risk ranges. 
Table 4. Sensitivity analysis of Scenario A

\begin{tabular}{crrrr}
\hline Input & $\begin{array}{c}\text { Change/Critical } \\
\text { volume }\end{array}$ & \multicolumn{2}{c}{ Parameters of economic justification } \\
\hline & Change (in \%) & NPV (EUR) & IRR (\%) & Payback (year) \\
\hline & $0 \%$ & 1.312 .721 & $24,43 \%$ & 4,1 \\
Production volume & $-10 \%$ & 903.951 & $20,19 \%$ & 5 \\
& $10 \%$ & 1.721 .491 & $28,56 \%$ & 3,5 \\
\hline Critical production volume (pcs) & 136 & 0 & $10 \%$ & $/$ \\
\hline & Change (in \%) & NPV (EUR) & IRR (\%) & Payback (year) \\
\hline & $0 \%$ & 1.312 .721 & $24,43 \%$ & 4,1 \\
Price of the cabin & $-10 \%$ & -47.164 & $9,40 \%$ & 9,1 \\
& $10 \%$ & 2.672 .605 & $37,49 \%$ & 2,6 \\
\hline Critical cab price (Euro / Cab) & 9.035 & 0 & $10 \%$ & $/$ \\
\hline & Change (in \%) & NPV (EUR) & IRR (\%) & Payback (year) \\
\hline & $0 \%$ & 1.312 .721 & $24,43 \%$ & 4,1 \\
Volume of investment & $-10 \%$ & 1.430 .007 & $27,28 \%$ & 3,8 \\
& $10 \%$ & 1.196 .343 & $22,10 \%$ & 4,5 \\
\hline Critical volume of investment & 2.720 .000 & 0 & $10 \%$ & $/$ \\
investments ( () & & & & \\
\hline
\end{tabular}

\subsection{Scenario B}

The usage of the innovative cabins which contain VGS has positive effects, for crane's owner and also to economy as whole. For the crane's possessor or holder, direct positive effect manifests through the increasing of the crane productivity. Cabins with integrated VGS allow faster and more efficient performing of work operations. It means that time saving due to faster task execution gives possibility to use crane to execute other jobs out of any extra cost. Reduction of crane usage annual costs due to new crane's cabin installation, which enables reduction of working operations time $(\Delta t)$, represents an advantage for the crane possessor or holder. Since the costs of crane exploitation depend on crane's working time, positive effect for crane owner, for the calculation purposes, represents the sum of a product of usage costs and weight of the average time saved $\left(\sum C E_{t} \cdot \rho_{t}\right)$.

Crane's exploitation annual costs could be disassembled to depreciation (recapitalization) costs, maintenance, overhaul and repair costs and insurance costs. The formula for calculation of exploitation annual costs is:

$\sum C E_{t}=P C \cdot P M T_{n}{ }^{i}+M C_{t}+R C_{t}+I C_{t}$

At equation (1), PC represents crane's purchase value, $P M T_{n}{ }^{i}$ is capital recovery factor for a certain lifetime of crane exploitation $(n)$, and i stands for the interest rate. Crane depreciation is regarded as the debt amortization e.g. future value of equal annual repayment of the amount invested in the procurement of the crane.

Average time saving weight is determined as relative ratio of the sum of the difference between the operations time performed with a novel cabins with VGS and operations time which is not including visual crane control management system integrated in the crane cabin:

$$
\rho_{t}=\frac{\sum_{j}^{N}\left(T_{j}^{1}-T_{j}^{2}\right)}{\sum_{j}^{N} T_{j}^{1}}
$$


At equation (2), $\rho_{t}$ stands for weight of average reduction of operation time with innovative cab implemented, $T_{j}{ }^{1}$ represents operations time without novel cab and $T_{j}^{2}$ represents amount of time when novel cab is installed.

The next benefit of novel solution is expressed by reducing labor expenditures. Assuming that the number of employees and the cost of working hour are still identical, reducing operation time gives employee time to do some extra work useful for the crane possessor/holder. Therefore, decrease of operational time $\left(\rho_{t}\right)$, enabled by implementation of proposed innovation, depicts the weight for calculating annual saving in costs of labor $\left(L S C_{t}\right)$ as a product of the number of employees, labor hour costs and number of crane's working hours:

$L S C_{t}=r \cdot h_{t} \cdot w_{h} \cdot \rho_{t}$

At equation (3) $L S C_{t}$ stands for savings of labor expenses in a year $(t), r$ is a number of crane operators, $h$ t $t$ stands for the number of crane's effective working hours in a year $(t)$, $w_{h}$ represents average working hour cost and $\rho_{t}$ stands for a weight of the average reduction of working hours per year $(t)$.

Installation of the novel solution of crane cabin enables reduction of incidence of occupational disorders and injuries of both crane operators and other workers on the site. This benefit can be quantified by reducing of number of days that operator spends during recovery period, and another employee is replacing him during this period. Formally, those expenses reduction is expressed by multiplying number of employees, number of lost hours due to absence of employee, hourly labor cost and average weight of time reduction on site caused by crane work:
$L S D C_{t}=r \cdot D h_{t} \cdot w_{h} \cdot \rho_{t}$

At equation (4), $L S D C_{t}$ reflects annual savings in labor costs when the crane operator is not working, $r$ represents a number of crane operators which work in cabin (if they are working in shifts), $D h_{t}$ is amount of lost working hours due to operator's paid sick days, $w_{h}$ stands for a cost of the operator's working hour and $\rho_{t}$ represents the weight of average crane operation time reduction per year $(t)$.

Through enabling clear view of the site, the novel cabin usage decreases the number of failures, decelerates wearing and tearing of moving parts and consequently decreases the cost of repair, preservation and maintenance of the crane. Calculation of those benefits is expressed by multiplication of the monetary value of the crane and difference in the crane annual maintenance, preservation and repair service costs:

$$
M R S C_{t}=P C \cdot\left[\frac{M R C_{t}^{1}}{P C}-\frac{M R C_{t}^{2}}{P C}\right]
$$

In equation (5) $M R S C_{t}$ stands for reduction of costs aimed to be spent for maintenance, preservation and repairs activities on annual level, $P C$ represents a monetary expression on the crane value, $M R C_{t}{ }^{1}$ stands for annual costs aimed to be spent on repairs and maintenance in case of the cabin which has not installed VGS and $M R C_{t}{ }^{2} \quad$ represents annual costs for maintenance, preservation and repairs in case of the novel cabin with environment detection potential.

Assumed lifespan of the crane is extended by proposed innovation implementation usage which results in more efficient transportation process. Proposed innovation through VGS installation also enables the 
exploitation lifespan extension and consequently lower costs of depreciation (recapitalization). It can be mathematically defined as the difference between recapitalized annual write-offs and the crane's lifetime $(n)$ when there is no installed novel cab with VGS and recapitalized annual reductions with the extended crane exploitation lifespan $(n+m)$ :

$$
E L S C_{t}=P C \cdot P M T_{n}{ }^{i}-P C \cdot P M T_{n}{ }^{i}+m
$$

At equation (6), $E L S C_{t}$ stands for depreciation write-offs savings on annual level, $P C$ is crane's purchase price, $P M T_{n}{ }^{i}$ represents capital recovery factor with the estimated period of exploitation without VGS $(n)$ with appropriate interest rate $(i)$, whereas $P M T_{n+m}^{i}$ is a capital recovery factor with the extended lifetime duration $(n+m)$ due to proposed innovation usage with appropriate interest rate $(i)$.

Crane cabin which has VGS installed will be evaluated through economic appraisal using cost-benefit framework to calculate achieved benefits while preserving savings. Net present value $(N P V)$ of an investment in the novel innovative crane cabin upgraded by VGS can be defined as the difference between the sum of initial investment costs and the sum of discounted savings over the entire crane's lifespan and calculated using the following mathematical expression:

$N P V=-\left(I_{0}+I_{1}\right)+\sum_{t}^{n+m} \frac{\left(C E_{t}+L S C_{t}+L S D C_{t}+M R S C_{t}+E L S C_{t}\right)}{(1+i)^{t}}$

At equation (7), $N P V$ stands for net present value of savings on costs of the crane usage achieved by upgrade with novel environment detection system over the crane usage time horizon $(n+m)$ whereas $(i)$ represents discount rate. Accordingly, $N P V$ has to be positive for economical justification of the project.

Internal rate of return of the venture is the value of discounted rate value which equates the difference between the initial costs for the acquisition of the cabin with VGS and the present value of the total savings on the costs with zero. Only if this rate exceeds the average weighted interest rate, the solution is economically justified.

Cost benefit ratio of the justifying of the novel crane cabin usage presents the relative ratio of total present value of the crane utilization saving and the costs of purchase, montage and acquiring of skills of the crane operator to the work in that cabin. The purchase of the crane cabin is economically justified only if, according to specified criteria, the value of this relative ratio is greater than one.

The estimated data is shown in Table 5 and, by using equations from (1) to (6), the values referred to the costs of acquisition and savings during the utilization period of novel cabins are calculated.

The net present value of the acquisition effect and the use of new cabins is described empirically using equation (7). The first step to calculate NPV is based on the best estimates of the values of variable models. At the discount rate of $10 \%$, net present value is $34.934,95$ euros. The cabin's purchase price is several times lower than the total economic benefit of the cabin usage in the total utilization period. That means that the project of installing the new generation cabin, as determined by this decisive factor, is justified. Internal rate of return is several times higher than the corresponding average weighted interest rate and its value amounts $37.39 \%$. This implies that profitability of this investment is high. Annual savings that are completed in the exploitation of the crane 
with cabin upgraded with VGS amount 6.746 euros. It means that the payback period is expected in a bit less than three years. Sensitivity and risk assessment is used to test the robustness of the established results. Sensitivity analysis gives the results shown in Table 6.

In the chosen variables in the span $\pm 10 \%$, the sensitivity analysis gives the relative stability of the results on changes. There is no significantly effect on the value of the criteria for assessing the economic justification of the procurement project and on usage of a novel cabins by the obtained results. The obtained critical cost of the crane (the value of the crane where the net profit of the savings is zero) amounts 69.960 euros. If the price of the cabin increases up to 56.346 eur, the project for procuring the cabin still will be economically justified. The variation of the value of the input economic parameters will not have a great affect to the period of return of funds invested in the purchase and installation of the new cranes cabin. The payback period is expected to vary between 2 and 3 years.

\section{Table 5. Economic cost-benefit appraisal inputs}

\begin{tabular}{|c|c|}
\hline Variables & Values \\
\hline \multicolumn{2}{|l|}{ Costs } \\
\hline $\begin{array}{l}\text { - Crane cabin production costs, including material costs, labor costs, energy } \\
\text { costs }-I_{0}\end{array}$ & 10.645 EUR \\
\hline $\begin{array}{l}\text { - Cabin assembly and testing costs, crane operator training for novel solution } \\
\text { usage and disassembly of the already existing cabin and its replacement with } \\
\text { novel cabin }\left(\mathrm{I}_{1}\right)\end{array}$ & 670 EUR \\
\hline \multicolumn{2}{|l|}{ Benefits } \\
\hline - Savings in transportation time /transportation cycle time reduction / $\left(\rho_{\mathrm{t}}\right)$ & $10 \%(8-12 \%)$ \\
\hline - Crane purchase price & $\begin{array}{r}268.000 \text { EUR } \\
(20,000-500,000)\end{array}$ \\
\hline - Annual savings on labor costs $\left(\mathrm{LSC}_{\mathrm{t}}\right)$. & 1.440 EUR \\
\hline $\begin{array}{l}\text { - Annual savings caused by reduced rate of occurence of professional diseases } \\
\text { and injuries of crane operators }\left(\mathrm{LSC}_{\mathrm{t}}\right)\end{array}$ & 400 EUR \\
\hline - Reduction of the crane maintenance, preservation and repair costs $\left(\mathrm{LSDC}_{\mathrm{t}}\right)$ & 1.655 EUR \\
\hline $\begin{array}{l}\text { - Savings caused by the extended exploitation lifespan - from } 15 \text { to } 18 \text { years } \\
\left(\text { ELSC }_{t}\right)\end{array}$ & 751 EUR \\
\hline
\end{tabular}

Table 6. Sensitivity analysis of Scenario B

\begin{tabular}{|c|c|c|c|c|}
\hline \multirow[t]{2}{*}{ Input } & Change/Savings/Cost & \multicolumn{3}{|c|}{ Parameters of economic justification } \\
\hline & Change (in \%) & NPV (EUR) & $\operatorname{IRR}(\%)$ & Payback (year) \\
\hline \multirow[t]{3}{*}{ The cost of the crane } & $0 \%$ & 34.860 & 37,33 & 2,75 \\
\hline & $-10 \%$ & 31.205 & 34,63 & 3,21 \\
\hline & $10 \%$ & 38.664 & 40,14 & 2,01 \\
\hline \multirow[t]{2}{*}{ Critical cost of crane } & 69.960 & 0 & $10 \%$ & / \\
\hline & Change (in \%) & NPV (EUR) & $\operatorname{IRR}(\%)$ & Payback (year) \\
\hline \multirow[t]{3}{*}{ Price of the cabin } & $0 \%$ & 34.860 & 37,33 & 2,75 \\
\hline & $-10 \%$ & 36.571 & 41,58 & 2,50 \\
\hline & $10 \%$ & 33.298 & 33,94 & 3,10 \\
\hline \multirow[t]{2}{*}{ The critical value of the cab } & 56.346 & 0 & $10 \%$ & 1 \\
\hline & Change (in \%) & NPV (EUR) & $\operatorname{IRR}(\%)$ & Payback (year) \\
\hline Savings in working hours & $0 \%$ & 34.860 & 37,33 & 2,75 \\
\hline The cost of the crane & $-10 \%$ & 34.631 & 37,16 & 2,81 \\
\hline The cost of the crane & $10 \%$ & 35.239 & 37,61 & 2,51 \\
\hline
\end{tabular}




\section{CONCLUSION}

The techno-economic analysis was carried out in this study in two different scenarios. In the first scenario A, the justification for the development, production and sale of crane cabins with VGS was economically assessed. For the projected capacity of 200 cabins per year, 20 years exploitation period and the selling price of 10.000 euros per cabin, the results show that the production of this type of cabins is economically justified with a net present value of 1.312.721 euros, an internal rate of return of $24.5 \%$ and the period of payback is four years. The results of the risk analysis in this scenario show a relatively significant reactivity of the values of the parameters of economic justification to reduce or increase the volume of cabin production. When production is reduced by $10 \%$, the net present value is reduced by $31 \%$ and the IRR by $18 \%$. In this case, the pay-back period will be extended for one year. The critical production volume is 136 cabins per year, which means that the scope of production can be reduced by 64 cabins, and that the whole project of building and exploitation of the factory is at the margin of economic justification. Changing the price of the cab has more dramatic effects on the performance of the project. Reducing the price of the cab by $10 \%$ leads the whole project of building and exploitation of the factory in loss, and the period of return on investment is extended to over 9 years. On the other hand, the increase in the cabin price by $10 \%$ increases the net present value by $103 \%$ and the internal rate of return by $54 \%$. All together, with this increase in the selling price, the repayment period of the invested is reduced to 2 years and 7 months. The cabin price limit, on which the effects cover costs, is 9.035 euros per cabin. If a production volume of 200 cabins is maintained annually, this is the price below which a potential investor should not go down.

Scenario B examines the economic justification for the use (purchase) of the cabin with VGS. Purchase of the previously described cabin crane is considered in this scenario as an investment of a potential user. Costs and effects in this scenario are calculated on the basis of the best estimate, and the second time based on the measured technical parameters.

The scenario B shows that the economic benefits of exploiting cabin with VGS in the entire exploitation period are several times higher than the purchase price of the innovative cabin. Following this decisive factor, procuring and installation process of "smart cranes" is justified through technoeconomic analysis. The internal rate of return is several times higher than the average weighted interest rate and involves high profitability of this investment. The annual savings achieved through the use of such a cab are realized in the pay-back period which is less than three years. In addition, the proposed project has very low risk. Societal impact of this project should not be neglected, too.

If both examined scenarios, $\mathrm{A}$ and $\mathrm{B}$, are viewed from a perspective of an average Serbian entrepreneur, it is necessary to continue this research by directing this towards a more economically viable, e.g. lower investment amount direction. Accordingly, the next research step would be the economic justification for installing VGS in an already existing crane cabin.

\section{Acknowledgements}

This paper is result of projects "Smart PRocess Industry CranEs" (SPRINCE), ERA-NET SAF€RA, funded by INAIL and MESTD and E!13300 funded by MESTD. 


\title{
ЕКОНОМСКА ОПРАВДАНОСТ КАБИНА КРАНОВА ОПРЕМЉЕНИХ РАЧУНАРСКИМ СИСТЕМОМ ВИЗУЕЛНОГ НАВОЪЕЊА У РЕАЛНОМ ВРЕМЕНУ
}

\author{
Никола Дондур, Весна Спасојевић Бркић, Александар Бркић, Мартина Бркић
}

\section{Извод}

Бројна истраживања у области несрећа у којима учествују дизалице указују на чињенице да је рад руковаоца/кранисте посао високог ризика и да је узрок несрећа и незгода најчешће људски фактор. Шодно томе, иновације на пољу унапређења индустријске безбедности процеса у којима учествују дизалице, у смислу помоћи кранисти да не направи грешку при руковању, су преко потребне. Пројекат “SPRINCE” за резултат има иновативно решење система за визуелно навођење у реалном времену, у циљу решавања проблема смањене видљивости из кранских кабина. Овај рад анализира економску оправданост система за визуелно навођење и на тај начин повезује људске, организационе и техничке факторе кроз приступ трошкова и користи. Анализирана су два предложена сценарија: А) производња и продаја кранских кабина са системом за визуелно навођење и Б) употреба (куповина) кранске кабине са системом за визуелно навођење. Техно-економска анализа показује да су економске користи у оба сценарија током периода коришћења више пута веће од набавне цене, док је интерна стопа приноса више пута већа од просечно пондерисане каматне стопе. Период повраћаја уложених средстава је мањи од четири године. Такође, оба пројекта припадају категорији пројеката ниског ризика.

Кључне речи: кранска кабина, систем за визуелно навођење, економска оправданост, безбедност

\section{References}

Ancione, G., Kavasidis, I., Merlino, G., \& Milazzo, M. F. (2017). Real-time guidance system for cranes to manage risks due to releases of hazardous materials. in L. Walls, M. Revie, T. Bedford Risk, Reliability and Safety: Innovating Theory and Practice. London, UK: Taylor and Francis Group, 742-749.

Ansaldi, S.M., Agnello, P., \& Bragatto, P.A. (2018). Smart safety systems: Are they ready to control the hazard of major accidents? WIT Transactions on the Built Environment, 174, 169-180.

Beavers, J.E., Moore, J.R., Rinehart, R.,
\& Schriver, W.R. (2006). Crane-related fatalities in the construction industry. Journal of Construction Engineering and Management, 132 (9), 901-910.

Chu, X.N., \& Thi, H. D. (2018). Determination of the Hazard Area of Crane and Hurdle-using Method for Accident Prevention. International Journal of Applied Engineering Research, 13 (9), 6717-6722.

Curry, S. \& Weiss, J. (2000). Project Analysis in Developing Countries. London, UK: MacMillan Press.

Dondur, N. (2002). Economic analysis of projects. Belgrade, RS: Faculty of Mechanical Engineering (In Serbian)

European agency for Safety and Health at 
work (2013): EU-OSHA Multi-Annual Strategic Programme (MSP) 2014-2020.

Fabiano, B. \& Currò, F. (2012). From a survey on accidents in the downstream oil industry to the development of a detailed near-miss reporting system. Process Safety and Environmental Protection, 90 (5), 357367.

Fang, Y., Chen, J., Cho, Y. K., Kim, K., Zhang, S., \& Perez, E. (2018). Vision-based load sway monitoring to improve crane safety in blind lifts. Journal of Structural Integrity and Maintenance, 3 (4), 233-242.

Marhavilas, P.K., Koulouriotis, D., \& Gemeni, V. (2011). Risk analysis and assessment methodologies in the work sites: On a review, classification and comparative study of the scientific literature of the period 2000-2009. Journal of Loss Prevention in the Process Industries, 24 (5), 477-523.

Milazzo, M.F., Ancione, G., Brkic, V.S., \& Vališ, D. (2016). Investigation of crane operation safety by analysing main accident causes. Pp. 74-80 in L. Walls, M. Revie, T. Bedford, Risk, Reliability and Safety: Innovating Theory and Practice. London, UK: Taylor and Francis Group

Neitzel, R.L., Seixas, N.S., \& Ren, K.K. (2001). A review of crane safety in the construction industry. Applied Occupational and Environmental Hygiene, 16 (12), 11061117.

Pinto, A., Nunes, I.L., \& Ribeiro, R.A. (2011). Occupational risk assessment in construction industry-Overview and reflection. Safety Science, 49 (5), 616-624.

Poh, C.Q., Ubeynarayana, C.U., \& Goh, Y.M. (2018). Safety leading indicators for construction sites: A machine learning approach. Automation in construction, 93, 375-386.

Puška, A., Beganović, A., \& Šadić, S. (2018). Model for investment decision making by applying the multi-criteria analysis method. Serbian Journal of Management, 13 (1), 7-28.

Rosenfeld, Y., \& Shapira, A. (1998). Automation of existing tower cranes: economic and technological feasibility, Automation in Construction, 7, 285-298.

Shin, I.J. (2015). Factors that affect safety of tower crane installation/dismantling in construction industry. Safety Science, 72, 379-390.

Skogdalen, J.E., \& Vinnem, J.E. (2011). Quantitative risk analysis offshore - Human and organizational factors. Reliability Engineering \& System Safety, 96 (4), 468479.

Spasojević Brkić, V., Klarin, M.M., \& Brkić, A.D. (2015a). Ergonomic design of crane cabin interior: The path to improved safety. Safety Science, 73, 43-51. 